\title{
Diana Isabel Hernández Santana
}

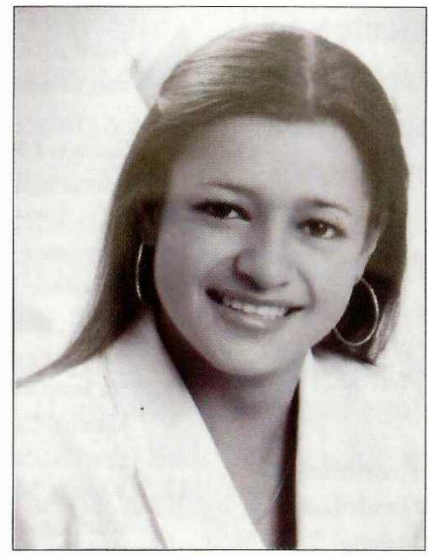

* 6 de diciembre de 1983

+ 25 de septiembre de 2010

Egresada de la Facultad de Enfermería

Nos unimos en estos momentos de tristeza, tratando de encontrar consuelo y resignación ante esta gran pérdida. Una alumna ejemplar que marcó la vida de muchas personas y que con su personalidad dejó huella en este mundo. Señor, quiero ofrecerte la vida de nuestra egresada para que todo unido a su sacrificio de vida, valga la pena y lo que ha tenido que pasar sea para la salvación de su alma. Ya no habrá para ella lágrimas, ni llanto, ni sobresaltos; el sol brillará para siempre sobre su frente y una paz intangible asegurará definitivamente sus fronteras... Con gran orgullo sólo nos resta decirte que descanses en paz. Te damos gracias por la vida, el conocimiento y el tiempo compartido, no es un adiós sino hasta pronto.

Yolanda Vallejo Pazmiño

Decana 